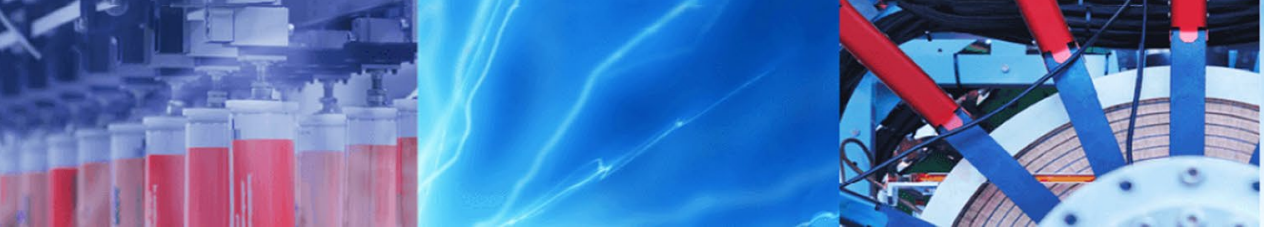

Research Article

\title{
An ecofriendly approach to decontaminate toxic metals from coal washery effluent using the mushroom Pleurotus ostreatus
}

\author{
Huma Vaseem ${ }^{1} \cdot$ Vinay Kumar Singh ${ }^{2} \cdot$ M. P. Singh ${ }^{3}$ (I)
}

Received: 15 June 2020 / Accepted: 19 August 2020 / Published online: 29 August 2020

(c) Springer Nature Switzerland AG 2020

\begin{abstract}
In this study, efforts have been made to detoxify the heavy metals ( $\mathrm{Mn}, \mathrm{Ni}, \mathrm{Zn}, \mathrm{Cu}, \mathrm{Pb}, \mathrm{Co}$ and $\mathrm{Cr}$ ) from coal washery effluent (CWE) using a macrofungi, Pleurotus ostreatus, in in vivo condition. For bioremediation purpose, different percentages of raw CWE soaked with paddy straw (substrate) were mixed with spawn of Pleurotus ostreatus macrofungi and these macrofungi were allowed to grow for certain time period. P. ostreatus decontaminated significant amount of metals from all the percentage of CWE, i.e. 75\% CWE, 50\% CWE and 25\% CWE, while its maximum bioremediation efficiency was found in $25 \%$ CWE. Percentage decrease in metals in 25\% CWE was as follows: Ni: 100\%, Zn: $99.04 \%$, Cu: 100\%, Co: 100\%, Cr: $100 \%, \mathrm{Mn}: 84.66 \%$ and $\mathrm{Pb}: 67.92 \%$. Metals accumulated $(\mathrm{mg} / \mathrm{Kg})$ in fruiting bodies of mushrooms grown on substrate containing CWE were found to be well below to their permissible level suggested by various international agencies for food materials. Increased activities of antioxidant enzymes, metallothionein concentration and lipid peroxidation and decrease in nutritional content were also noticed in fruiting bodies grown on substrate containing CWE in comparison with control group. Present study suggests that Pleurotus can be used as a promising option for removal of heavy metals from the effluent released from washery plants.
\end{abstract}

Keywords Antioxidant enzymes $\cdot$ Coal washery effluent $\cdot$ Metal accumulation · Mycoremediation $\cdot$ Nutritional content

\section{Introduction}

One of the great problems for coal washery industries is the dumping of effluent released after washing of coal that contains impurities such as heavy metals (like nickel, lead, iron, chromium, manganese, copper, cobalt, aluminium, arsenic, cadmium, etc.), fine particles of coal and many other pollutants [1, 2]. Huge amount of water and different materials like detergents, coagulants, flocculant and surfactant are used during processing of coals in coal washery plants which ultimately produce a significant quantity of effluent [3]. Discharge of this coal washery effluent into the river and other wetlands causes adverse effects on the aquatic organisms as it contains many of the non-biodegradable elements that have deleterious impact on animal physiology [4].

To overcome the problem of CWE pollution, treatment of these waste waters before their discharge into the water bodies is very important. Many methods such as ion exchange method, electrochemical treatment, use of membrane technologies and chemical precipitation are being used at large scale in different industries to decontaminate the contaminated environment [5]. However, these methods are very costly, not suitable to the environment and not much effective [6]. Hence, it is very important to develop a fast, cost-effective and ecofriendly method for eliminating heavy metals from effluent such as CWE. Use of mushroom in remediation of toxic elements

$\triangle$ M. P. Singh, mpsingh.16@gmail.com | 'Department of Zoology, Faculty of Life Sciences, Aligarh Muslim University, Aligarh 202001, India. ${ }^{2}$ C.M.P College, University of Allahabad, Allahabad 211002 , India. ${ }^{3}$ Centre of Biotechnology, University of Allahabad, Allahabad 211002, India. 
has been increased many folds in recent years. It is known to have high metal binding capacity due to its high percentage of cell wall [7] and can also detoxify or convert toxic substance to less toxic form [8]. These are the reasons why macrofungi are considered as a promising option for remediation process.

There are several in vitro studies in which mushrooms were used for remediation of heavy metals from the synthetic media [9-11]. But, in vivo use of mushroom for decontamination of natural waste water released from different industries is scanty. Recently, it has been tried to decontaminate the CWE using P. ostreatus in vitro condition and reported significant decrease in metals from CWE [2]. Therefore, this study is designed to examine the role of $P$. ostreatus in decontamination of metals from CWE in vivo condition. The source of studied CWE was a Coal Washery Plant of BCCL (Bharat Coking Coal Limited), Dhanbad, India.

For remediation purpose, content of various metals $(\mathrm{Cr}$, $\mathrm{Ni}, \mathrm{Pb}, \mathrm{Co}, \mathrm{Mn}, \mathrm{Zn}$ and $\mathrm{Cu}$ ) in the grown mushrooms and in their paddy substrate soaked with different percentages of CWE, i.e. $75 \%$ CWE, $50 \%$ CWE and $25 \%$ CWE, was examined. Adverse impact of CWE on mushroom health was also manifested by measuring antioxidant enzyme activities, lipid peroxidation (LPO) and metallothionein proteins concentration in the fruiting bodies.

Apart from remediation efficiency, mushrooms are also beneficial for hypercholesteraemic patients as it influences the lipid profile and also improves the antioxidant condition $[12,13]$. They are also a good source of several elements ( $\mathrm{Cu}, \mathrm{Zn}, \mathrm{Mo}$, Se and Fe), and they are involved in many important biochemical [14]. Although metals are required in trace amount for normal metabolic process and growth of mushroom, their excess amount may lead to severe physiological problems resulting low-quality mushrooms with reduced nutritional values. Hence to know the effect of CWE on the nutritional content of the mushrooms, protein, lipid, ash and fibre contents were also analysed in the fruiting bodies grown on substrate soaked in different percentages of CWE.

\section{Materials and methods}

\subsection{Maintenance of mushroom culture and collection of CWE}

The culture of $P$. ostreatus was obtained from Directorate of Mushroom Research, Solan (Himachal Pradesh), India. Malt dextrose agar (MDA) medium (temperature $25 \pm 2{ }^{\circ} \mathrm{C}$ and $\mathrm{pH} 6-6.5)$ was used as culture media. Culture was subcultured at every three weeks of interval. CWE was collected in five containers each having capacity of $100 \mathrm{~L}$, from a coal washery plant of Bharat Coking Coal Limited (BCCL), Jharkhand, India.

\subsection{Preparation of spawn}

Spawn is the vegetative growth of fungus grown on cereal grains. Method of Singh et al. [15] was used to prepare the spawn. Washed wheat grains were half boiled and spread over a tilted platform to remove excess water, and then, buffers $\left(\mathrm{CaCO}_{3}\right.$ and $\mathrm{CaSO}_{4}$ in 3:1 ratio) were mixed with them. Bottles were half filled with wheat grain and were plugged by cotton. These bottles were autoclaved at the temperature $121^{\circ} \mathrm{C}$ and pressure $15 \mathrm{psi}$ for $30 \mathrm{~min}$ and left for overnight. Then after inoculation of bottles was done by transferring inoculums of $P$. ostreatus from cultured plate and these filled bottles were incubated in incubation chamber at a temperature of $25 \pm 2{ }^{\circ} \mathrm{C}$.

After 3-4 days of inoculation, the fungal mycelium started to spread on the grains in the form of white net web-like mycelia. After 18-21 days, white mycelial growth was observed in entire bottles.

\subsection{Preparation of paddy straw substrate and spawning}

Before preparation of substrate, dilution of the CWE was done with distilled water (DW) in three combinations, i.e. $75 \% \mathrm{CWE}+25 \% \mathrm{DW}, 50 \% \mathrm{CWE}+50 \% \mathrm{DW}$ and $25 \%$ CWE $+75 \%$ DW. Raw effluent (100\% CWE) was also kept along with diluted CWE. Substrate was prepared by dipping the $2 \mathrm{~kg}$ small piece of paddy straw in $8 \mathrm{~L}$ of distilled water (taken as control), pure and diluted CWE separately and kept at RT for overnight. Next morning, spawning of substrate was carried out, i.e. $30 \mathrm{~g}$ spawn grains were mixed with each $1000 \mathrm{~g}$ wet substrate which was further tightly packed in polythene bags. In this way, six bags of each CWE-soaked group were prepared along with distilled water-soaked group (control). In last at the bottoms of each bag $(1 \times 1 \mathrm{~cm}), 12$ holes were made to remove extra moisture and entry of air. All the spawned bags were kept in mushroom house for 45 days on metal rack for growth analysis of mushroom. After full growth of fruiting bodies, they were collected from each group on 35 th day and 42nd day for study of various metal concentration and nutritional parameters. Fruiting bodies are full grown mushrooms that comprise of stem, cap and gills which are what eaten by people (Fig. 1). Substrates were also collected along with fruiting bodies from each group for metal analysis. 
Fig. 1 Growth of fungal mycelia on substrate soaked with different percentages of CWE. a Growth of fungal mycelia on substrate soaked with $100 \%$ CWE. b Growth of fungal mycelia on substrate soaked with $75 \%$ CWE. c Growth of fungal mycelia on substrate soaked with 50\% CWE. d Growth of fungal mycelia on substrate soaked with $25 \%$ CWE. e Growth of fruiting bodies on substrate soaked with $75 \%$ CWE. $f$ Growth of fruiting bodies on substrate soaked with $50 \%$ CWE. g Growth of fruiting bodies on substrate soaked with $25 \%$ CWE
(A)

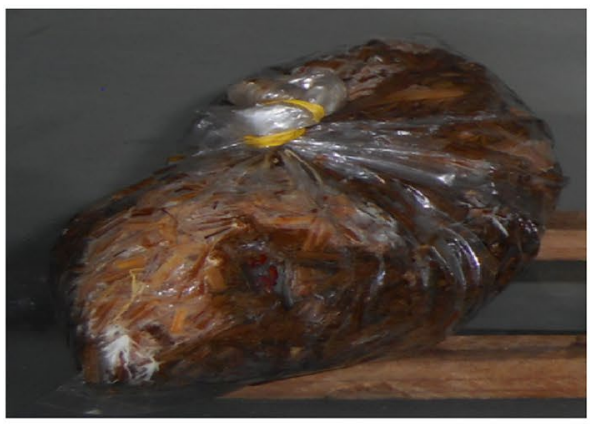

(C)

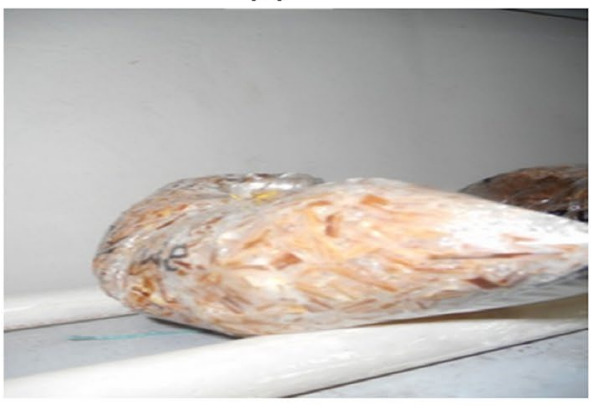

(E)

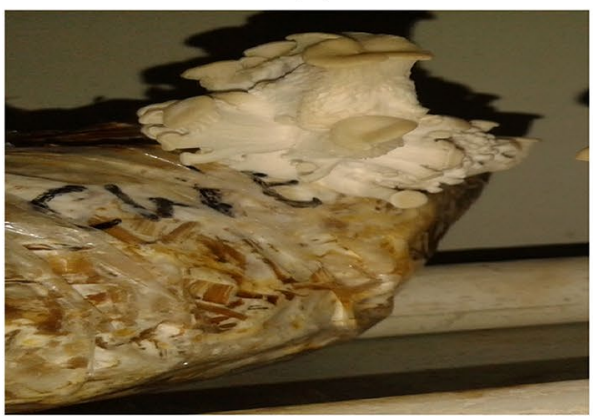

(B)

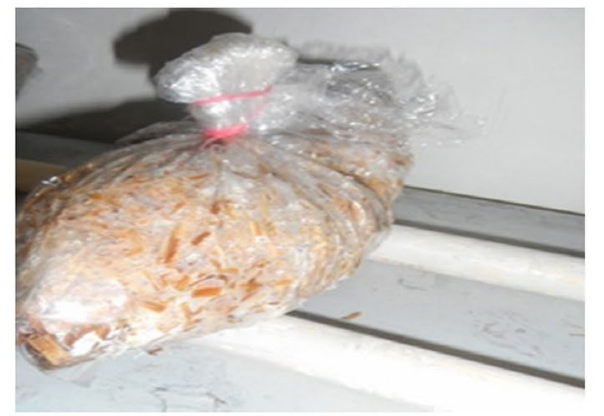

(D)

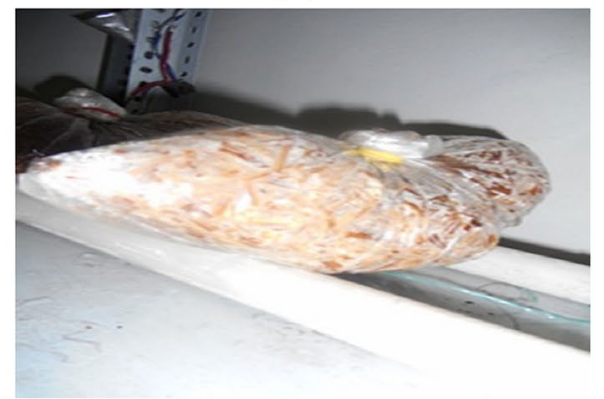

(F)

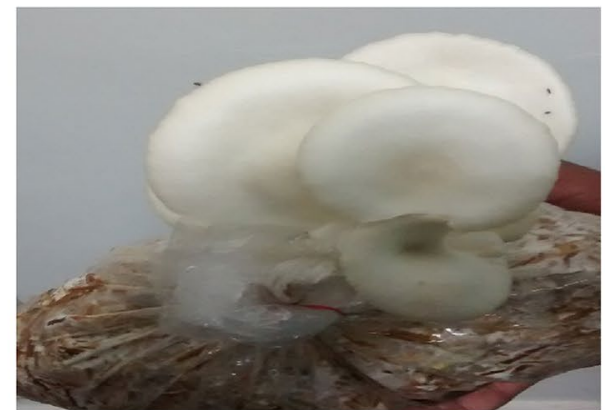

(G)

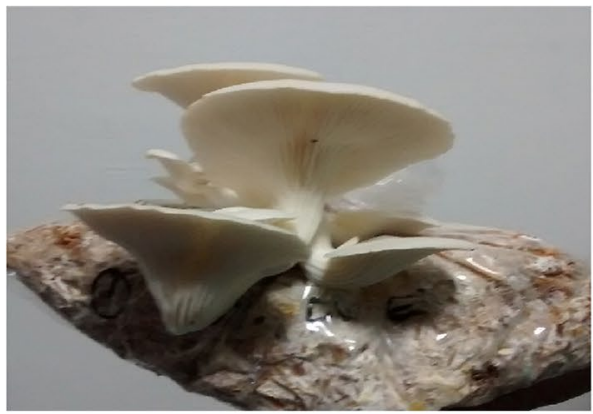

\subsection{Growth analysis of fungus grown on paddy substrate}

The growth of fungus can be divided into mycelial stage, pinhead stage, early fruit body stage and mature fruit body stage. The day when fungus was spawned, mycelial growth was not seen which was denoted by a negative sign (-). We observed the growth of fungus after 7-day interval and measured its mycelial growth in terms of positive sign (+). Each positive sign (+) represents the $10 \%$ mycelial growth, and it was maximum (100\%) in control (DW-soaked substrate) group after 21 days of spawning, then after pinhead 
Table 1 Growth of fungal mycelia grown on paddy straw soaked with different percentages of CWE

\begin{tabular}{|c|c|c|c|c|c|}
\hline Days & Control & $100 \%$ CWE & $75 \%$ CWE & $50 \%$ CWE & $25 \%$ CWE \\
\hline 1st day & ---------- & ---------- & ---------- & ---------- & ----------- \\
\hline 7th day & ++--------- & ---------- & ---------- & ---------- & ++--------- \\
\hline 14th day & ++++++---- & ---------- & ++++------- & ++++++---- & ++++++---- \\
\hline 21 st day & ++++++++++ & ---------- & ++++++++-- & +++++++++- & ++++++++++ \\
\hline 28th day & Pin stage & ----------- & ++++++++++ & Pin stage & Pin stage \\
\hline 35th day & Fruit body & ---------- & Pin stage & Fruit body & Fruit body \\
\hline 42nd day & Fruit body & --------- & Fruit body & Fruit body & Fruit body \\
\hline
\end{tabular}

One + shows $10 \%$ growth, and - represents no growth in fungal mycelia stage started to appear followed by early fruit body and mature fruit body stages (Table 1).

\subsection{Heavy metal analysis in fruiting bodies and paddy substrate}

Five gram of fruiting bodies from each group were dried in Petri dish in an oven at $120^{\circ} \mathrm{C}$ till there was no further weight loss. Dried fruiting bodies and substrate were kept into digestion flasks having a mixture of nitric acid and perchloric acid $(4: 1 \mathrm{v} / \mathrm{v})$. Then after digestion flask was heated on a hot plate at $120^{\circ} \mathrm{C}$ so that all materials get dissolved in acids. After complete digestion, double-distilled water was added to sample to make the volume up to $25 \mathrm{ml}$. Concentration of metals ( $\mathrm{Mn}, \mathrm{Ni}, \mathrm{Zn}, \mathrm{Cu}, \mathrm{Pb}, \mathrm{Co}$ and $\mathrm{Cr}$ ) was analysed using inductively coupled plasma mass spectrophotometry (ICP-MS).

\subsection{Analysis of antioxidant enzyme activities in fruiting bodies}

For the antioxidant enzymes assay, homogenate of fungal tissue was prepared in ice cold $0.1 \mathrm{M}$ phosphate buffer saline ( $\mathrm{pH} 7.0)$. Centrifugation was done at $2500 \mathrm{rpm}$ for $10 \mathrm{~min}$, at $4{ }^{\circ} \mathrm{C}$ followed by second centrifugation at $12,000 \mathrm{~g}$ for $20 \mathrm{~min}$ at $4{ }^{\circ} \mathrm{C}$. The supernatants were then kept at $-80^{\circ} \mathrm{C}$ for enzyme estimation. Then after total protein in the supernatant was measured using Lowry et al. [16]. Method of Das et al. [17] was used for analysis of SOD activity (Unit/mg protein) in fungal tissue using reaction cocktail containing phosphate buffer, a-methionine, Triton X-100, HAC and EDTA and Griess reagent. For CAT assay (nmole/mg/sec), Aebi [18] method was used. Its assay mixture had phosphate buffer, $\mathrm{H}_{2} \mathrm{O}_{2}$ and enzyme extract. LPO in fungal tissue (nmoles TBARS/mg protein) was analysed by method given by Ohkawa et al. [19] using reaction cocktail (SDS, acetic acid, thiobarbituric acid and butylated hydroxyl toluene).

\subsection{Analysis of metallothionein concentration in fruiting bodies}

Viarengo et al. [20] method was used to estimate total metallothionein concentration. Ellman's reagent was used for its assay. Detail of the procedure has been described by Vaseem et al. [2].

\subsection{Analysis of nutritional content in fruiting bodies}

\subsubsection{Total protein}

Mushroom was homogenised in phosphate buffer and centrifuged at $4000 \mathrm{rpm}$. Resulting precipitate was dissolved in $0.5 \mathrm{~N} \mathrm{NaOH}$ and centrifuged at $7000 \mathrm{rpm}$, and obtained clear solution was used for estimation of protein concentration using method of Lowry et al. [16].

\subsubsection{Total lipid}

Estimation of total lipid was done by the method of Folch et al. [21] by extracting lipid in extraction solvent (chloroform:methanol 2:1 v/v).

\subsubsection{Crude fibre}

Crude fibre was determined by method of Raghuramulu et al. [22].

\subsubsection{Total ash}

For determination of ash content, mushroom sample was heated in a muffle furnace (in atmospheric conditions) for about 5-6 h at $600{ }^{\circ} \mathrm{C}$ and sample was then cooled in a desiccator and weighed.

Then, total ash was calculated as (Raghuramulu et al. [22]):

Ash content $(\mathrm{g} / 100 \mathrm{~g}$ sample $)=$ weight of ash $\times 100 /$ weight of sample taken. 


\subsection{Statistical analysis}

Data are presented as mean \pm standard deviation $(n=3)$. One-way analysis of variance (ANOVA) followed by the Duncan's Multiple Range Test (DMRT) was used to find out significant difference between the two mean values. Differences were considered significant at the level of $p<0.05$. In tables and figures, alphabets denote the result of DMRT. Different alphabets show significant difference $(p<0.05)$ in the different values of means.

\section{Results and discussion}

\subsection{Physicochemical characteristics of CWE}

The effluent was found to be highly contaminated with many heavy metals which were present above their permissible limits (Mn: $14.63 \mathrm{mg} / \mathrm{l}, \mathrm{Ni}: 1.789 \mathrm{mg} / \mathrm{l}$, Zn: $4.458 \mathrm{mg} / \mathrm{l}, \mathrm{Cu}: 2.337 \mathrm{mg} / \mathrm{l}, \mathrm{Pb}: 45.355 \mathrm{mg} / \mathrm{l}$, Co: $3.514 \mathrm{mg} / \mathrm{l}, \mathrm{Cr}: 1.123 \mathrm{mg} / \mathrm{l}$ ) [2]. Other physicochemical parameters of the CWE were as follows: total dissolved solid (mg/l): $739 \pm 169.44$, total suspended solids (mg/l): $4624.333 \pm 323.62$, turbidity (NTU): $27.667 \pm 2.517$, electrical conductivity $(\mu \mathrm{S} / \mathrm{cm}): 1.063 \pm 0.118$, BOD $(\mathrm{mg} / \mathrm{l})$ : $65.821 \pm 5.43$, hardness $(\mathrm{mg} / \mathrm{l}): 413 \pm 7.211$, phosphate (mg/l): $35.78 \pm 3.324$, nitrate (mg/l): $28.46 \pm 4.98$ [2].

\subsection{Effect of different percentages of CWE on growth of fungus}

Growth of fungal mycelia on the substrate soaked with different percentages of CWE is shown in Table 1 and Fig. 1. The mycelia grown on different percentages of CWE have shown different levels of growth stages. From Table 1 and Fig. $1 \mathrm{~A}$, it can be clearly seen that fungal mycelia could not grow on the substrate soaked with 100\% (raw) effluent. High concentration of different toxic metals in the raw effluent might have caused severe effects on the growth of mycelia and did not allow them to survive (Fig. 1A). The fruiting bodies grown on the substrate containing 50\% CWE (Fig. 1F) and 25\% CWE (Fig. 1G) showed good and continuous growth in comparison with the mycelia grown on $75 \%$ CWE (Fig. 1E) (growing at a slower speed and developed pinhead stage later). The dilution of CWE caused decrease in concentration of different metals in the CWE which led to the normal growth of the mycelia in diluted effluents like $75 \%, 50 \%$ and $25 \%$ effluent and made mycelia efficient for metal accumulation from the CWE and supported in its normal growth. Higher content of metals in the $75 \%$ CWE in comparison with the $50 \%$ and $25 \%$ diluted effluent might be the cause of late growth of mycelia and distorted fruiting bodies in $75 \%$ diluted CWE.
Maximum growth was observed in control group, and pinhead stage and fruiting bodies growth was seen first in control than other groups.

\subsection{Efficiency of $P$. ostreatus in remediation of heavy metals from CWE}

Remediation efficiency of Pleurotus for heavy metals from CWE was investigated from 0 day (spawn condition) to 42nd day (fully grown fruiting bodies) of exposure on the substrate soaked with different percentages of CWE. The data from $100 \%$ CWE grown fungus are not included in the results because the mycelia could not grow on it.

Figure $2 \mathrm{~A}$ shows bioremediation of different metals like $\mathrm{Ni}, \mathrm{Zn}, \mathrm{Cu}, \mathrm{Co}, \mathrm{Cr}, \mathrm{Mn}$ and $\mathrm{Pb}$ from the substrate soaked with $75 \%$ CWE. From Fig. 2A, it can be clearly seen that significant $(p<0.05)$ amount of all the metals have been remediated from the substrate from 0 day to 35 th day to $42 \mathrm{nd}$ day. The percentage decrease in metal concentration in 75\% CWE was as follows Ni: $87.76 \%$, Zn: $91.54 \%$, Cu: 100\%, Co: $62.36 \%, C r: 66.39 \%, \mathrm{Mn}: 86.95 \%$ and $\mathrm{Pb}: 82.38 \%$.

Figure $2 \mathrm{~B}$ shows concentration of metals accumulated in the fungus fruiting bodies after bioremediation of substrate soaked with $75 \%$ CWE. From the figure, it can be clearly seen that concentration of all the metals significantly increased in fruiting bodies from 0 day to 42 nd day. The final concentration of metals in the fruiting body after mycoremediation was as follows (mg/kg): $\mathrm{Mn}: 8.56$, Ni: 1.12, Zn: 2.762, Cu: 0.959, Pb: 27.023, Co: 1.482, Cr: 2.261 (Table 3).

In the $50 \%$ and $25 \%$ CWE containing substrates, significant decrease in different metals was observed from 0 day to 42 nd day (Figs. $3 a$ and $4 a$, respectively). In 50\% CWE, the percentage decrease in different metals was as follows: Ni: $98.36 \%$, Zn: $89.52 \%$, Cu: $100 \%$, Co: $89.98 \%, C r: 88.80 \%$, $\mathrm{Mn}: 72.89 \%$ and $\mathrm{Pb}: 78.18 \%$, while in case of $25 \% \mathrm{CWE}$, the decrease was as follows: Ni: $100 \%, \mathrm{Zn}: 99.04 \%, \mathrm{Cu}: 100 \%$, Co: $100 \%, C r: 100 \%, \mathrm{Mn}: 84.66 \%$ and Pb: $67.92 \%$. Percentage decrease in concentration of most of the metals was maximum in the substrate soaked with 25\% CWE in comparison with the $75 \%$ and $50 \%$ CWE. This shows the maximum bioremediation efficiency of Pleurotus in 25\% CWE. Decreased metal concentration caused less accumulation of metals in the fruiting bodies in diluted effluent that has direct effect on its growth. Percentage decrease in metals from all the diluted effluents is shown in Table 2. Significant difference in the decrease in most of metals was also observed in all the diluted effluents $(p<0.05)$. Many researches have been performed that reported capability of metal build-up of an organism depends upon its environmental metal concentration [23-26]. Milovanovic et al. [27] reported that $P$. ostreatus mycelium had good growth and biomass yield in low concentration of metal, while its 
(A)
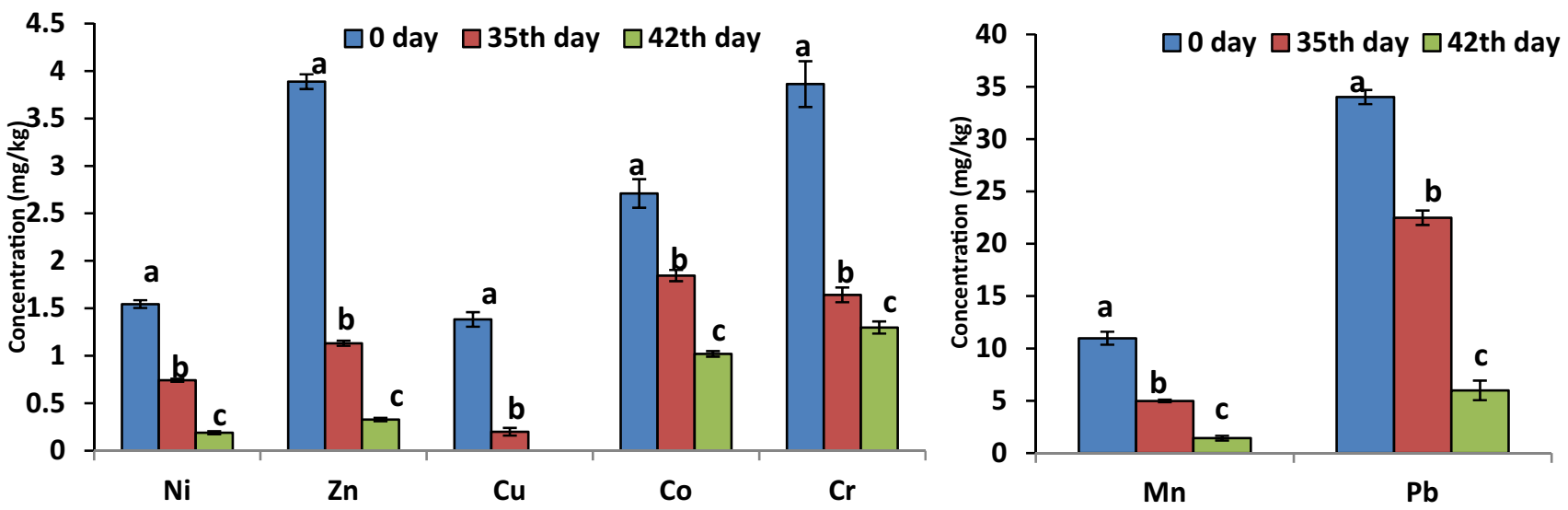

(B)
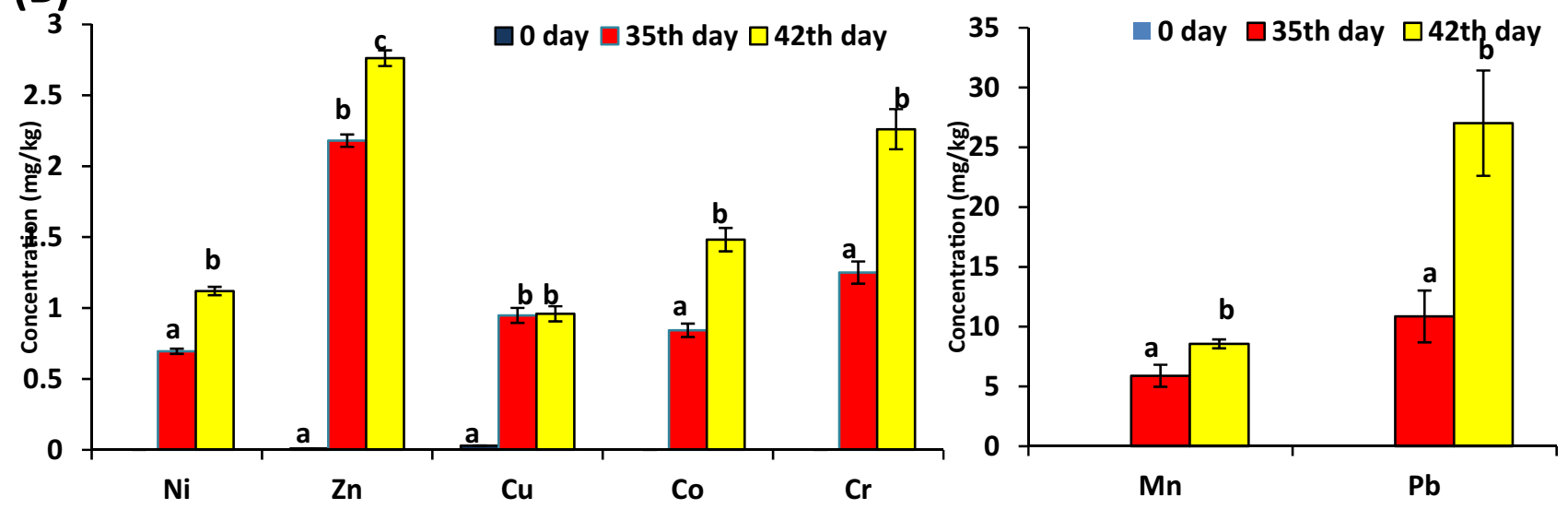

Fig. 2 a Metals concentration in substrate soaked with 75\% CWE. b Metals concentration in fruiting bodies grown on substrate soaked with $75 \%$ CWE

growth and biomass yield reduced in higher concentration of metals. In this way, result of present study shows that metal concentration in the environment decides an organisms' ability of metal accumulation.

Low concentration of metals in diluted effluents has less toxic effects on the fruiting bodies and makes the fruiting bodies capable for removing significant amount of metals from CWE. This can be demonstrated by the significant accumulation $(p<0.05)$ of different metals in mushrooms grown on substrate soaked with $75 \%, 50 \%$ and $25 \%$ CWE from 0 day to 42 nd day (Figs. 2b, $3 \mathrm{~b}$ and 4b). In control groups, there were no significant changes observed in metals concentration in fruiting bodies as well as in substrate.

The final concentration of metals in the fruiting bodies grown on substrate soaked with $75 \%, 50 \%$ and $25 \%$ CWE is shown in Table 3. From Table 3, it can be clearly demonstrated that all the metals (except $\mathrm{Pb}$ ) in fruiting bodies grown on different percentages of effluent were well below than their permissible limits suggested by various international agencies for food materials. Significant difference was also observed in most of the metals in all the diluted effluents $(p<0.05)$. Many researchers have also reported accumulation of various metals in the fruiting bodies of natural growing mushrooms and found their concentration below the level suggested by various agencies $[28,29]$.

\subsection{Antioxidant enzyme activities in fruiting bodies}

There was significant alteration observed in antioxidant enzymes activities in fruiting bodies grown on different percentages of CWE (Table 4). Activity of SOD, catalase and LPO in $50 \%$ and $25 \%$ CWE increased from 0 day to 42 nd day, while catalase activity did not show any significant difference in $75 \%$ CWE from 35th day to 42 nd day. Antioxidant enzymes are capable of protecting the organisms by stabilising and deactivating the reactive oxygen species 

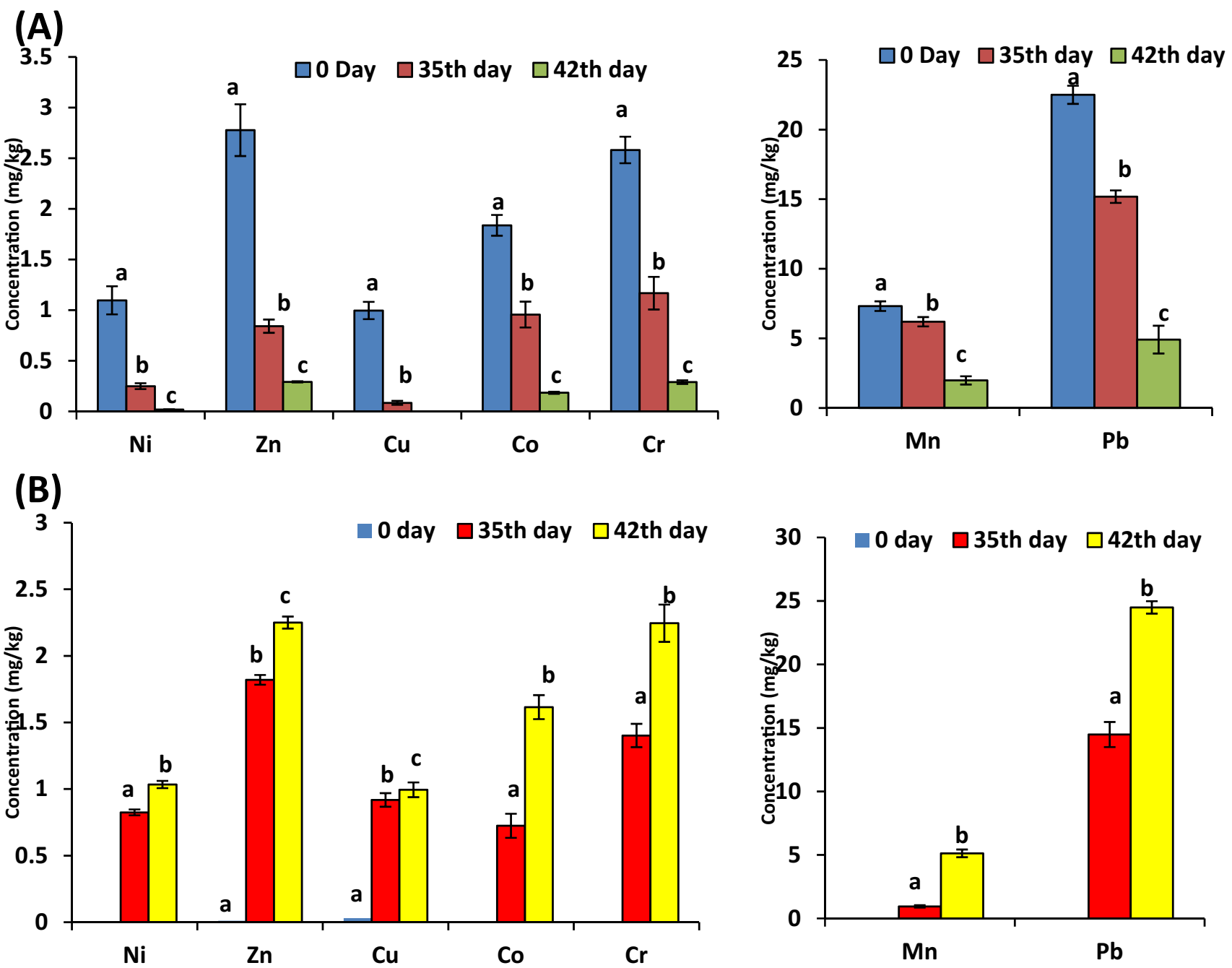

Fig. 3 a Metals concentration in substrate soaked with 50\% CWE. b Metals concentration in fruiting bodies grown on substrate soaked with $50 \%$ CWE

(one of the major causes of oxidative stress) produced my metals and other toxicants [30,31]. Increased activities of antioxidant enzyme in $50 \%$ and $25 \%$ effluent grown mushrooms might be for protection of fungus from stress of heavy metals. Many researchers have also reported increased antioxidant enzymes activity in macrofungi exposed to metals [32-34]. High amount of metals in the $75 \%$ might have responsible interruption in the antioxidant systems, and fungus did not withstand the damage caused by accumulated metals.

\subsection{Metallothionein concentration in fruiting bodies}

Metallothioneins (cysteine-rich proteins) have high capacity to bind with metals. In this way, they protect the cells from adverse effect of metals [35]. In present study, increase in metallothionein concentration might be resulted to save the mushrooms from the metals accumulated in fungal mycelium grown on CWE [36]. Figure 5 denotes concentration of metallothionein protein in the fruiting bodies cultivated on substrate soaked with different percentages of CWE on 42nd day of experiment. It illustrates that metallothionein concentration was found to be significantly higher $(p<0.05)$ in the fruiting bodies grown on substrate containing CWE than the fruiting bodies of control group. Increase in metallothionein concentration is due to accumulation of various metals in fruiting bodies.

\subsection{Nutritional content in the mushrooms}

Mushrooms are highly nutritious having high protein content, fibre, sugar, minerals and high quantity of amino 


\section{(A)}
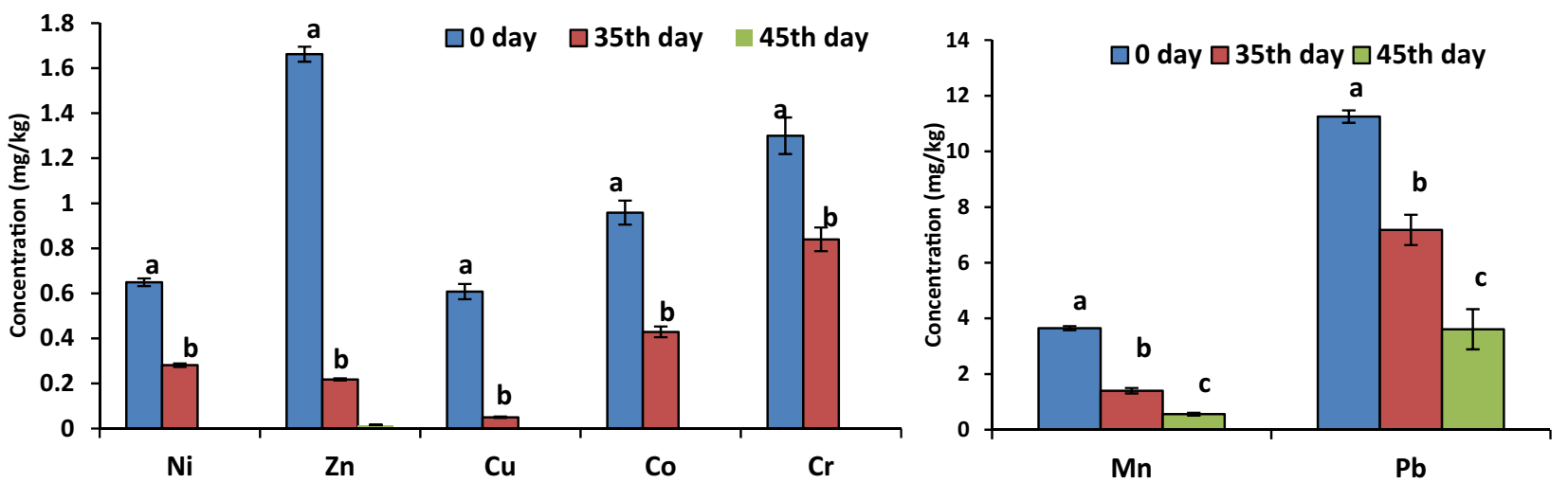

(B)
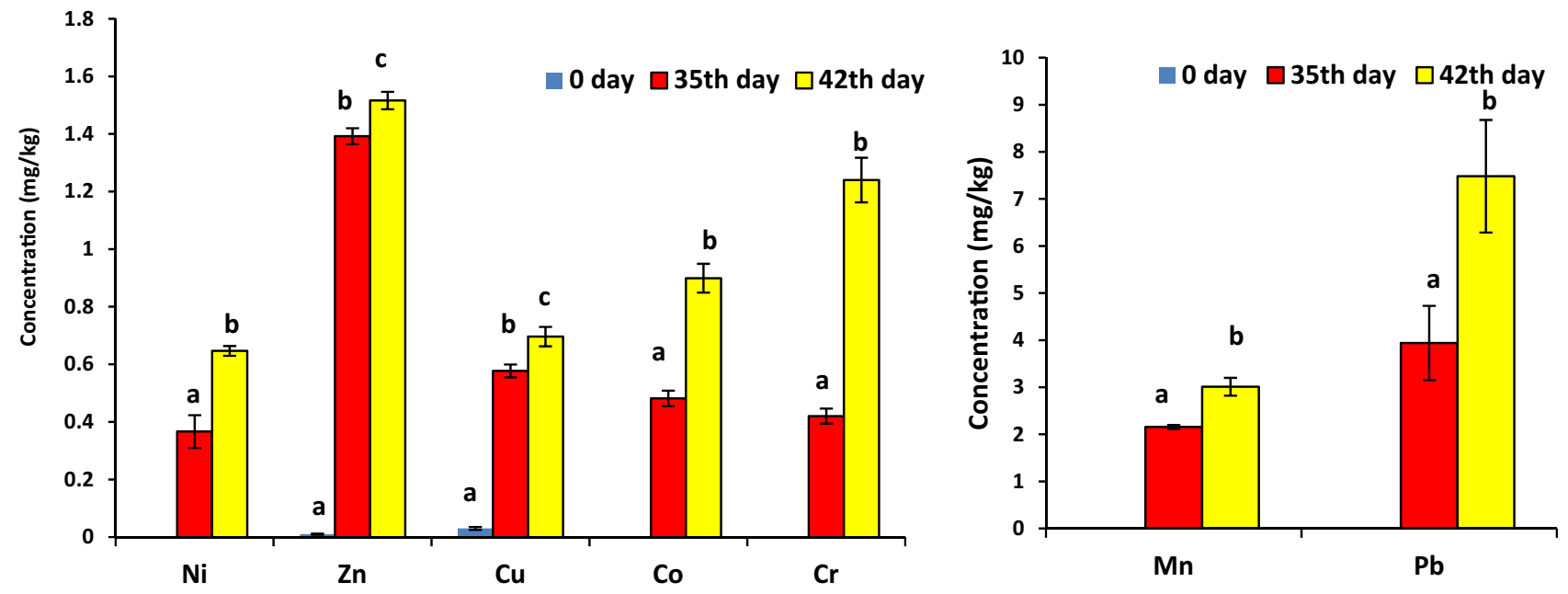

Fig. 4 a Metals concentration in substrate soaked with 25\% CWE. b Metals concentration in fruiting bodies grown on substrate soaked with $25 \%$ CWE

Table 2 Percentage decrease in the concentration of metals from the substrate soaked with different percentages of CWE after bioremediation using $P$. ostreatus on 42 nd day

\begin{tabular}{llll}
\hline Metals & $75 \%$ CWE & $50 \%$ CWE & $25 \%$ CWE \\
\hline $\mathrm{Mn}$ & $86.95^{\mathrm{a}} \%$ & $72.89^{\mathrm{b}} \%$ & $84.66^{\mathrm{c}} \%$ \\
$\mathrm{Ni}$ & $87.76^{\mathrm{a}} \%$ & $98.36^{\mathrm{b}} \%$ & $100^{\mathrm{c}} \%$ \\
$\mathrm{Zn}$ & $91.54^{\mathrm{a}} \%$ & $89.52^{\mathrm{b}} \%$ & $99.04^{\mathrm{c}} \%$ \\
$\mathrm{Cu}$ & $100^{\mathrm{a}} \%$ & $100^{\mathrm{a}} \%$ & $100^{\mathrm{a}} \%$ \\
$\mathrm{~Pb}$ & $82.38^{\mathrm{a}} \%$ & $78.18^{\mathrm{b}} \%$ & $67.92^{\mathrm{c}} \%$ \\
$\mathrm{Co}$ & $62.36^{\mathrm{a}} \%$ & $89.98^{\mathrm{b}} \%$ & $100^{\mathrm{c}} \%$ \\
$\mathrm{Cr}$ & $66.39^{\mathrm{a}} \%$ & $88.80^{\mathrm{b}} \%$ & $100^{\mathrm{c}} \%$ \\
\hline
\end{tabular}

Letters show result of DMRT. Different letters denote significant changes $(p<0.05)$ among different means
Table 3 Final concentration of metals in the fruiting bodies grown on substrate soaked with different percentages of effluent on last day of bioremediation (42nd day)

\begin{tabular}{lllll}
\hline Metals & $75 \%$ CWE & $50 \%$ CWE & $25 \%$ CWE & Permissible limits \\
\hline $\mathrm{Mn}$ & $8.56^{\mathrm{a}}$ & $5.122^{\mathrm{b}}$ & $3.010^{\mathrm{c}}$ & $\begin{array}{c}400-1000 \mathrm{mg} / \mathrm{kg}(\mathrm{WHO} \\
1992)\end{array}$ \\
$\mathrm{Ni}$ & $1.12^{\mathrm{a}}$ & $1.034^{\mathrm{b}}$ & $0.646^{\mathrm{c}}$ & $\begin{array}{c}100-300 \mathrm{mg} / \mathrm{kg}(\mathrm{WHO} \\
1994)\end{array}$ \\
$\mathrm{Zn}$ & $2.762^{\mathrm{a}}$ & $2.250^{\mathrm{b}}$ & $1.516^{\mathrm{c}}$ & $60 \mathrm{mg} / \mathrm{kg}(\mathrm{WHO} 1992)$ \\
$\mathrm{Cu}$ & $0.959^{\mathrm{a}}$ & $0.994^{\mathrm{a}}$ & $0.696^{\mathrm{b}}$ & $40 \mathrm{mg} / \mathrm{Kg}(\mathrm{WHO} 1992)$ \\
$\mathrm{Pb}$ & $27.023^{\mathrm{a}}$ & $24.492^{\mathrm{b}}$ & $7.481^{\mathrm{c}}$ & $10 \mathrm{mg} / \mathrm{Kg}(\mathrm{WHO} 1998)$ \\
$\mathrm{Co}$ & $1.482^{\mathrm{a}}$ & $1.615^{\mathrm{b}}$ & $0.899^{\mathrm{c}}$ & Not known \\
$\mathrm{Cr}$ & $2.261^{\mathrm{a}}$ & $2.245^{\mathrm{a}}$ & $1.240^{\mathrm{b}}$ & $120 \mathrm{mg} / \mathrm{kg}$ (FDA 1993) \\
\hline
\end{tabular}

Letters show result of DMRT. Different letters denote significant changes $(p<0.05)$ among different means 

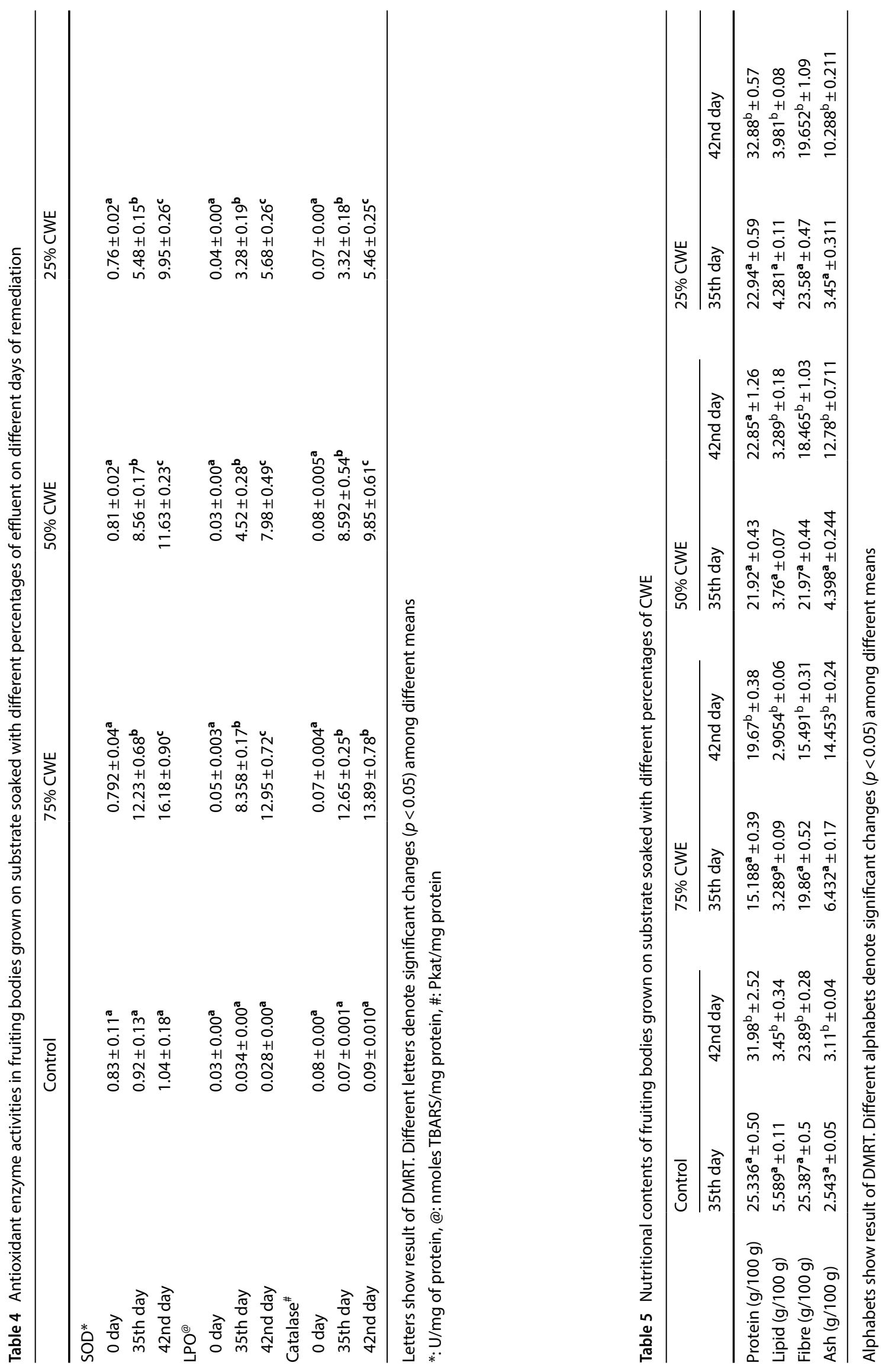
Fig. 5 Metallothionein concentration in fruiting bodies grown on substrate soaked with different percentages of CWE

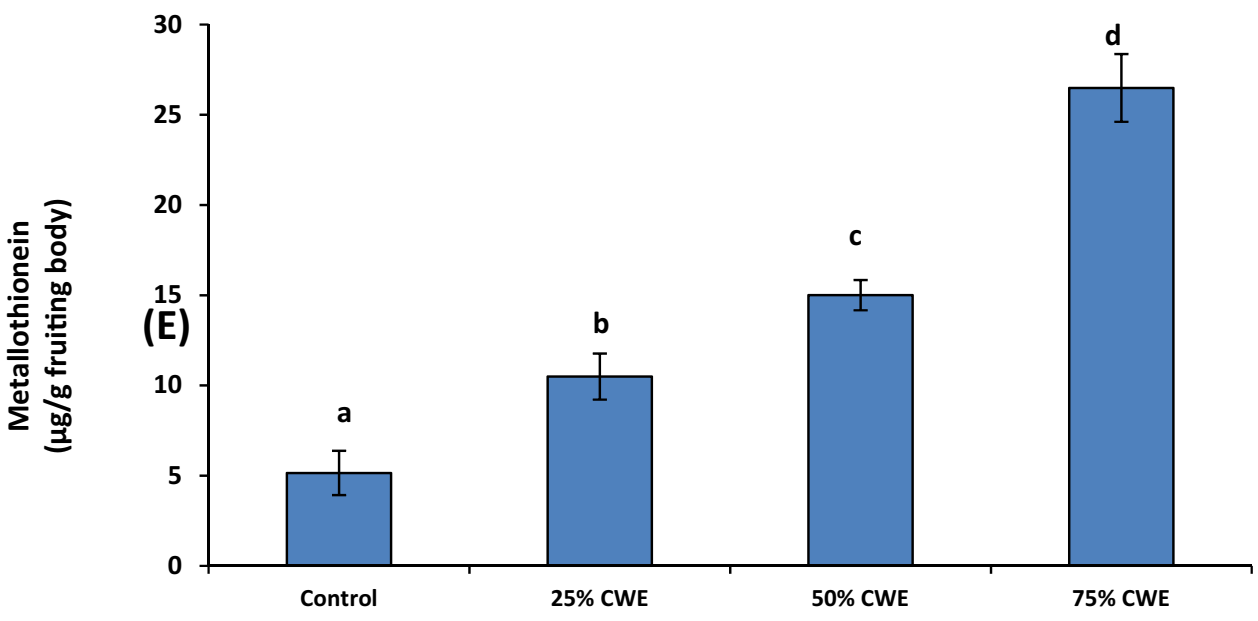

acids like phenylalanine, threonine and tyrosine $[37,38]$. As they are good source of various nutrients, it is also very important to analyse different nutritional contents of mushrooms cultivated on CWE. Hence, the effect of coal washery effluent was accessed by studying different nutritional contents of the mushroom fruiting bodies like total protein, total lipid, ash and fibre content (Table 5). The protein, lipids and fibre contents in the mushrooms grown on all percentage of CWE were found to be lower than those of control ones except in 25\% CWE grown mushrooms in which protein content was higher in comparison with the control. The decreased protein, lipids and fibre content might be due to toxic effect rendered by heavy metals present in the CWE on the mushroom's physiology. Increased concentration of ash in all the fruiting bodies cultivated on substrate with CWE in comparison with control (Table 5) might be the result of accumulated metals in the fruiting bodies grown on CWE.

\section{Conclusion}

Mycoremediation of coal washery effluent using a macrofungi Pleurotus ostreatus was found to be highly significant resulting decrease in concentration of metals from CWE. Metal accumulation was also observed in the fruiting bodies grown on different percentages of the CWE having metal concentration below than their permissible level suggested by different international agencies for food materials. Alteration in antioxidant enzyme activities and concentration of metallothionein proteins in fruiting bodies were also observed showing protective mechanism of mushroom against toxic effect of heavy metals present in effluent. The decreased nutritional content of the fruiting bodies grown on CWE in comparison with control ones was also the evidence of CWE toxicity.
Acknowledgements Dr. Huma Vaseem gratefully acknowledges University Grants Commission (UGC), New Delhi, India, for providing fellowship Dr. D.S. Kothari Postdoctoral Fellowship (No. F.4-2/2006 (BSR)/BL/13-14/0315) to carry out this work. Authors are also thankful to Coordinator, ISLS (Interdisciplinary School of Life Sciences), Banaras Hindu University, for providing ICP-MS facility.

Authors' contributions Huma Vaseem carried out experiments, wrote the manuscript and prepared tables and figures. Vinay K. Singh contributed equally in commencement of experiments and preparation of manuscript. Prof. M.P. Singh conceived the idea, supervised the complete work and edited the manuscript.

Funding The chemicals, glassware and consumables used in the experiments were procured from contingency grant of Dr. D.S. Kothari Postdoctoral Fellowship of University Grant Commission, New Delhi, India, provided to Dr. Huma Vaseem.

\section{Compliance with ethical standards}

Conflict of interest The authors declared that they have no conflict of interest.

\section{References}

1. Bandopadhyay $P$ (1995) Impact and abatement of pollution in coal and mineral processing. Workshop of Mining Environment, ENVIS Center, CME, ISM, Dhanbad

2. Vaseem H, Singh VK, Singh MP (2017) Heavy metal pollution due to coal washery effluent and its decontamination using a macrofungus, Pleurotus ostreatus. Ecotoxicol Environ Saf 145:42-49

3. Khoury DL (1981) Coal cleaning technology. Park Ridge. Kulshreshtha S, Mathur N, Bhatnagar, New Tessey

4. Ghose MK (1999) Sustainable supplies of water for coal washeries in India. Sci Total Environ 229:217-225

5. Li X, Zeng GM, Huang JH, Zhang C, Fang YY, Qu YH, Luo F, Lin D, Liu HL (2009) Recovery and reuse of surfactant SDS from a MEUF retentate containing $\mathrm{Cd} 2 \mathrm{p}$ or $\mathrm{Zn} 2 \mathrm{p}$ by ultrafiltration. J Membr Sci 337:92-97

6. Wang J, Chen C (2006) Biosorption of heavy metals by Saccharomyces cerevisiae: a review. Biotechnol Adv 24:427-451 
7. Gadd GM (2007) Geomycology: biogeochemical transformations of rocks, minerals, metals and radionuclides by fungi, bioweathering and bioremediation. Mycol Res 111:3-49

8. Raj DD, Mohan B, Vidya BM (2011) Mushrooms in the remediation of heavy metals from soil. Int J Environ Poll Cont Manag 3:89-101

9. Damodaran D, Shetty KV, Mohan B (2013) Effect of chelaters on bioaccumulation of Cd (II), Cu (II), Cr (VI), Pb (II) and Zn (II) in Galerina vittiformis from soil. Int Biodeterior Biodegrad 85:182-188

10. Damodaran D, Balakrishnan RM, Shetty VK (2013) The uptake mechanism of $\mathrm{Cd}(\mathrm{II}), \mathrm{Cr}(\mathrm{VI}), \mathrm{Cu}(\mathrm{II}), \mathrm{Pb}(\mathrm{II})$, and $\mathrm{Zn}$ (II) by mycelia and fruiting bodies of Galerina vittiformis. BioMed Res Int 2013:1-11

11. Klein JM, Anziliero S, Camassola M, Grisa AMC, Brandalise RN, Zeni M (2012) Evaluation of metal biosorption by the fungus Pleurotus sajor-caju on modified polyethylene films. J Bioremed Biodeg 3:152

12. Hossain MS, Alam N, Amin SMR, Basunia MA, Rahman A (2007) Essential fatty acids content of Pleurotus ostreatus, Ganoderma lucidum and Agaricus bisporus. Bangladesh J Mushroom 1:1-7

13. Jayakumar T, Thomas PA, Sheu JR, Geraldin P (2011) In-vitro and In-vivo antioxidant effects of the oyster mushroom Pleurotus ostreatus. Food Res Int 44:851-861

14. Zaidman BZ, Yassin M, Mahajna J, Wasser SP (2005) Medicinal mushroom is modulators of molecular targets for cancer therapeutics. Appl Microbiol Biot 2:1-24

15. Singh MP, Pandey VK, Srivastava AK, Vishwakarma SK (2011) Biodegradation of Brassica haulms by white rot fungus $P$. eryngii. Cell Mol Biol 57:47-55

16. Lowry $\mathrm{OH}$, Rosebrough NJ, Farr AL, Randall RJ (1951) Protein measurement with the folin phenol reagent. J Biol Chem 193:265-275

17. Das K, Samanta L, Chainy GBN (2000) A modified spectrophotometric assay of superoxide dismutase using nitrite formation of superoxide radicals. Int J Biochem Biophys 37:201-204

18. Aebi H (1984) Catalase in vitro. In: Colowick SP, Kaplane NO (eds) Methods in enzymology, vol 105. Academic Press, New York, pp 121-127

19. Ohkawa H, Ohishi N, Yagi K (1979) Assay for lipid peroxides in animal tissues by thiobarbutric acid reaction. Anal Biochem 95:351-358

20. Viarengo A, Ponzano E, Dondero F, Fabbri R (1997) A simple spectrophotometric method for metallothionein evaluation in marine organisms: an application to Mediterranean and Antarctic molluscs. Mar Environ Res 44:69-84

21. Folch J, Lees M, Sloane-Stanely GH (1957) A simple method for the isolation and purification of total lipids from animal tissues. J Biol Chem 226:497-509

22. Raghuramulu N, Madhavan NK, Kalyanasundaram S (2003) A manual of laboratory techniques, pp 56-58.

23. Chen XH, Zhou HB, Qiu GZ (2009) Analysis of several heavy metals in wild edible mushrooms fromregions of China. Bull Environ ContaminToxicol 83:280-285
24. Basile A, Sorbo S, Aprile G, Conte B, Castaldo CR (2008) Comparison of the heavy metal bioaccumulation capacity of an epiphytic moss and an epiphytic lichen. Environ Pollut 151:401-407

25. Gonzalez MC, Gonzalez RC, Wright SF, Nichols KA (2004) The role of glomalin, a protein produced by arbuscular mycorrhizal fungi, in sequestering potentially toxic elements. Environ Pollut 130:317-323

26. Turkekul M, Elmastas T (2004) Determination of iron, copper, manganese, zinc, lead, and cadmium in mushroom samples from Tokat, Turkey. Food Chem 84:389-392

27. Milovanović I, Brčeski I, Stajić M, Korać A, Vukojević J, Knežević A (2014) Potential of Pleurotus ostreatus mycelium for selenium absorption. Sci World J. https://doi.org/10.1155/2014/681834

28. Zhu F, Qu L, Fan W, Qiao M, Hao H, Wang X (2010) Assessment of heavy metals in some wild edible mushrooms collected from Yunnan province, China. Environ Monit 6:1725-1728

29. Medhanye G, Negussie M, Abi M (2016) Levels of essential and non-essential metals in edible mushrooms cultivated in Haramaya, Ethiopia. Int J Food Contam. https://doi.org/10.1186/ s40550-016-0025-7

30. Xiulan X, Zhouqing H, Nifan C, Zizhong T, Qiang W, Yi C (2019) Roles of environmental factors in regulation of oxidative stress in plant. BioMed Res. https://doi.org/10.1155/2019/9732325

31. Stohs SJ, Bagchi D (1995) Oxidative mechanisms in the toxicity of metal ions. Free Radic Biol Med 18:321-336

32. Ott T, Fritz E, Polle A, Schu A, Schutzendubel A (2002) Characterisation of antioxidative systems in the ectomycorrhiza-building basidiomycete Paxillus involutus (Bartsch) Fr. and its reaction to cadmium. FEMS Microbiol Ecol 42:359-366

33. Jacob C, Courbot M, Brun A, Steinman HM, Jacquot JP, Botton B, Chalot M (2001) Molecular cloning, characterization and regulation by cadmium of a superoxide dismutase from the ectomycorrhizal fungus Paxillus involutus. Eur J Biochem 268:3223-3232

34. Yildirim N, Asma D (2010) Response of antioxidant defense system to cadmium-induced toxicity in white rot fungus Phanerochaete chrysosporium. Fresenius Environ Bullt 19:3059-3065

35. Cobbett C, Goldsbrough P (2002) Phytochelatins and metallothioneins: roles in heavy metal detoxification and homeostasis. Annl Rev Plant Biol 53:159-182

36. Zafar S, Aqil F, Ahmad I (2007) Metal tolerance and biosorption potential of filamentous fungi isolated from metal contaminated agricultural soil. Bioresour Technol 98:2557-2561

37. Paul S (1993) Growing gourmet and medicinal mushrooms. Ten Speed Press, Berkeley

38. Jonathan SG (2002) Vegetative growth requirements and antimicrobial activities of some higher fungi from Nigeria. Ph.D Thesis University of Ibadan. Ibadan Nigeria

Publisher's Note Springer Nature remains neutral with regard to jurisdictional claims in published maps and institutional affiliations. 